\title{
Employee Career: Effect of Administrative Competence, Social Capital and Performance
}

\author{
Nia Kusuma Wardhani ${ }^{1}$, Wibowo ${ }^{2}$, Hamidah ${ }^{3}$ \\ Doctoral Programme of Human Resource Management at Jakarta State University and Lecturer Mercu \\ Buana University, Indonesia ${ }^{1}$ \\ Lecturer Jakarta State University, Indonesia ${ }^{2}$ \\ Lecturer Jakarta State University, Indonesia ${ }^{3}$
}

\begin{abstract}
As organization grows and develops in dynamic globalization, employee is a valuable asset for organization and the need for qualified human resources is increases. The purpose of this research is aims to examine the influence of Administrative Competence, Social Capital and Performance to Employee Career of Mercu Buana University, using path analysis method in quantitative approach. Sample of this research was 185 employees of Mercu Buana University. Result of this research indicates that there is direct effect of competence to employee career which values 0,259 , there is direct effect of performance to employee career which values 0,218 , there is direct effect of social capital to employee career which values 0,213 , there is direct effect of competence to performance which values 0,342 , there is direct effect of social capital to performance which values 0,300 . Thus it can be explained that the most direct influence to Employee Career and Performance is Competence.
\end{abstract}

\section{Keywords : Competence, Social Capital, Performance, Career}

\section{Introduction}

In an increasingly dynamic competition, it is important to consider how the competencies, performance and employee social capital affect employee opportunities to innovate that have implications for career success. Ibarra in Aime (2012) describes improving relationships in the workplace can improve employee competence, identity and effectiveness of professional roles.

In the case of employees working, will certainly experience the process of adapting to the work environment, where employees as members of the organization play an active role in the progress and development of the organization through its performance is supported by adequate competence according to the operational needs of the organization.

In order to be able to do its job well, employees must meet the required competencies and accompanied the maximum effort so that its performance is good and supports the organization in achieving the goal. Thus employees are an asset to the organization.

Chen et al (2015) explains that rewards and job opportunities aim to help employees achieve their goals and also foster professional skills that employees will be more motivated to improve their career growth than to move to other companies. Individual factors such as proactive nature and social capital can also benefit a person's career growth.

Weng in S.Napitupulu et al (2017) perceptions about careers is career growth referring to promoted opportunities, gaining career development experience, remuneration, increased responsibility and professional ability. To get that goal, employees must show their performance.

The management of the University of Mercu Buana is always trying to motivate employees to improve their performance that impact on improving the quality of administrative services to students. But there are problems in the management of employees because there is no regular rotation so that employees feel bored, lack of opportunities for self-development and not achieving individual goals, especially in terms of career improvement. 
As an individual, every employee must have their own career planning. In the case of a planned career, it certainly relates directly to income (income), power and status, which ultimately impact on job satisfaction. Thus can be determined free variable in this study is the competence and social capital, while the dependent variable in this study is the performance and career of employees.

\section{Objectives}

The purpose of this research is to analyze direct effect of Administrative Competence on Employee Career, to analayze direct effect of performance on Employee Career, to analyze direct effect of Social Capital on Employee Career, to analyze direct effect of Administrative Competence on Performance, to analyze direct effect of Social Capital on Performance.

\section{Literature Review \\ Employee Career}

According to Hani Handoko in Sunyoto (2015) the definition of a career is a sequence of promotion to positions that are more demanding responsibility in or cross the hierarchy of employment relations during one's working life. Sunyoto explains Employees who have job performance tend to improve in their career, employees also need to be known by people who decide on promotions, transfers and other career opportunities.

Weer (2017) found that managers' perceptions of a strong commitment of employees to the organization greatly affected the chances of career growth and strongly committed employees tended to improve their career.

Noe (2010) argues that those who succeed in careers are employees who continue to perform well. The willingness to sacrifice for the company is also needed (such as accepting new tasks or moving to different areas). Good oral and written communication skills, ease in interpersonal relationships, and talent for leadership are essential.

Caluwe (2014) explains that today many employees are thinking about organizational career mindset. But only highly educated employees, investing in careers and networking (social network), have an infinite career mindset.

Sutanto in Sutrisno (2012), an important factor for career success, is being able to position oneself appropriately, dare to face risks and challenges responsibly; and able to communicate seamlessly with various parties.

The significant indicators of career are: 1) Desire promoted, 2) Ability to adapt, 3) Exposure, 4) Communication skills, 5) Achievement trends.

\section{Administrative Competence}

According to Nuryanto (2017), competence is part of personality and behavior that is deep and attached to a person. Competence can cause or be used to predict a person's performance, meaning that if it has a high competence, it will have a high performance as well.

Nuryanto et al. (2017) argues that competency-based human resources can improve capacity and build foundations because if the people who work in the organization have the right competence in accordance with the demands of their work, then he will be able both in terms of knowledge, skills and mental and productive character .

Del Corso dalam Coetzee et al (2015) berpendapat bahwa "Individuals must be flexible, proactive, embrace lifelong learning, seek out new skills, and think globally in order to keep up with the pace of change and comply with the requirements of employers".

According to Moeheriono (2012), competency indicator is motive, trait, self concept, skill, knowledge. Koh (2015) argues that Key competencies needed for successful job performance of professionals including abil $\neg$ to learn, ability to collaborate, ability to serve diverse people.

According to Dharma in Wirotomo (2015), Competence includes behavioral characteristics that can indicate the difference between those who perform high performance. Hutapea (2008) explains to achieve sustainable achievement needed to be confident to be able to interact with the environment around the work, able to cooperate with officials from other parts and has a flexible nature.

The employees of the University of Mercu Buana referred to in this study are educational personnel, in accordance with Law no. 12 of 2012 on Higher Education and in Article 39 of the National Education System Law no. The competence that must be owned by employees of Mercu Buana University is the ability 
and knowledge of employees to carry out the work in the conduct of lecturing at Mercu Buana University includes administrative, management, development, supervision and technical services to support the lecturing process.

It is synthesized that competence is the ability of a person to carry out administrative, management, development, supervision and technical services to support the lecture process which enables him to deliver superior performance to achieve success in his work.

The competency indicator in this research is: a) Having knowledge, b) Having skill, c) Having work attitude, d) Self-controlling, e) Self-confidence, f) Flexibility, g) Ability to build relationship.

\section{Social Capital}

According to Atthoillah (2017), social capital in the organization is characterized by mutual social interaction among employees and management based on the deep-rooted beliefs within an organizational culture and social ethics. So there arises an employee entity that has a togetherness about the values of honesty, discipline, togetherness, and the importance of hard work-smart in improving the resulting performance.

Coleman in Creed (2015) defines "Social capital, which is a fundamental human resource reflecting these social connections."

In modern life today, various ways are done to foster social relationships with the environment. This social network is one way how people engage individual relationships with individuals or individuals with groups. Social network is one dimension of social capital besides trust and norms.

Suh (2016) determines the social capital indicator as follows: social capital which includes aspects such as trust, mutual senses of identification, shared norms, and perceived obligations, as well as positive relationships and high levels of intimacy between actors.

Thobias (2013): Fujiwara and Kawachi say that social capital is the resources accessed by individuals and groups within a social structure, facilitating cooperation, collective action, and preservation of norms. Hasbullah also explains that there are six main elements in social capital that is participation in network, reciprocity, trust, social norm, values and proactive. In the workplace, being friends can be said to be networking, we should not limit our potential for networking, because we never know when we need them, but we also need to help when they need as reciprocity. In building the network as a social capital, can be done formally or informally networking approach.

In a friendship relationship requires integrity and honesty. Both form the basis of essential trust for long term personal and interpersonal cooperation and growth.

The significant indicators of social capital are: a) Be honest, b) Integrity, c) Follow rules, d) Reciprocity, e) Ability to make personal contact, f) Ability to interact socially.

\section{Performance}

Rivai (2013) explains that performance is a real behavior that is displayed every person as a work performance generated by employees in accordance with its role in the company. Performance appraisal is a formal and structured system used to measure, assess and influence job-related, behavioral and outcome characteristics, including absenteeism.

According to Wibowo (2014), performance is about doing the work and the results achieved from the work. Performance is about what to do and how to do it.

Dalal (2014) explains that dynamic performance fluctuates within employees over time. Employees will be more productive if in a happy state (mood cycle), creative and proactive behavior. It is important for organizations to explicitly set time frame constraints to employees as a consequence of their work.

The indicators used in the assessment of employee performance are as follows: a) Accuracy of completion of work, b) Loyalty, c) Responsibility, d) Be disciplined. 


\section{Research Methods}

This research is a quantitative research with unit analysis of Mercu Buana University, using Path Analysis method, with a population of 344 employees. The Slovin formula is used to determine the number of samples, with a fault margin tolerance of $5 \%$, so the sample size is 185 employees.

\section{Result And Discussion \\ Validity and Reliability}

At the trial stage the instrument was taken 30 (thirty) respondents. Test the validity of research instruments using Pearson Product Moment Correlation Test. Empirically in the test of this instrument, the level of significance is set at $\alpha=0.05$, with the sample number 30 then the degrees of freedom is 28 . Thus the value obtained in Table $r$ is 0.361. If a item has a value of $r_{\text {counted }}>r_{\text {table, }}$, it is declared valid, and vice versa if $r_{\text {counted }}<r_{\text {table }}$, it is declared invalid, so the invalid item is dropped or is considered void.

Table 1. Validity and Reliability Test Result

\begin{tabular}{|l|c|c|c|c|}
\hline \multirow{2}{*}{ Variable } & \multicolumn{2}{|c|}{ Validity Test Result } & \multicolumn{2}{c|}{ Reliability Test Result } \\
\cline { 2 - 5 } & $\begin{array}{c}\text { Valid } \\
\text { Questions }\end{array}$ & $\begin{array}{c}\text { Invalid } \\
\text { Questions }\end{array}$ & $\begin{array}{c}\text { Alpha } \\
\text { Cronbach } \\
\text { Value }\end{array}$ & $\begin{array}{c}\text { Assumption } \\
\text { of Reliability }\end{array}$ \\
\hline Competence & 30 & 1 & 0.881 & High \\
\hline Social Capital & 23 & 2 & 0,887 & High \\
\hline Performance & 20 & 2 & 0.904 & Perfect \\
\hline Employee Career & 20 & 3 & 0.816 & High \\
\hline
\end{tabular}

Based on Table 1, it can be seen that all variables have a value of Cronbach's alpha> $r_{\text {table, so all variables is }}$ declared reliable and can be forwarded for data collection.

\section{Linierity and Significant Regression Test}

The linearity test and regression significance are done by using SPSS software where Constants and coefficients of linear regression equation are obtained from column B in Coefficients table. and positive influence seen from table Anova in column F where Fcount $>$ Ftable and value of significance p-value <0,05.

The linearity test of the regression equation is determined by ANOVA Table where the relationship between variables meets the linear assumption if the Deviation From Linierity value Fcount <Ftable and the p-value value $>0.05$ then the regression equation is linear. While the Regression Significance Test is obtained from the Regression line in the ANOVAa table where the value Fcount $>$ Ftable and p-value $=0<0.05$ then the regression equation is stated very significant.

Table 2. Linierity and Regression Significance Test Result

\begin{tabular}{|l|l|l|l|l|l|l|l|}
\hline \multirow{2}{*}{ Variabel } & \multicolumn{3}{|c|}{ Uji Linieritas } & \multirow{2}{*}{$\begin{array}{l}\text { Linierity } \\
\text { Result }\end{array}$} & \multicolumn{2}{c|}{$\begin{array}{l}\text { Uji } \\
\text { Significantsi }\end{array}$} & \multirow{2}{*}{$\begin{array}{l}\text { Significant } \\
\text { Result }\end{array}$} \\
\cline { 2 - 3 } & $\mathbf{F}_{\text {hitung }}$ & $\mathbf{F}_{\text {table }}$ & \multicolumn{1}{|c|}{ Sig. } & & $\mathbf{F}_{\text {hitung }}$ & $\mathbf{F}_{\text {table }}$ & \\
\hline $\mathrm{X} 1 \rightarrow \mathrm{Y}$ & 1,540 & 1,75 & $0,102>0,05$ & Linier & 45,981 & 3,89 & Significant \\
\hline $\mathrm{X} 3 \rightarrow \mathrm{Y}$ & 1,298 & 1,61 & $0,180>0,05$ & Linier & 42,110 & 3,89 & Significant \\
\hline $\mathrm{X} 2 \rightarrow \mathrm{Y}$ & 1,164 & 1,62 & $0,290>0,05$ & Linier & 38,223 & 3,89 & Significant \\
\hline $\mathrm{X} 1 \rightarrow \mathrm{X} 3$ & 1,176 & 1,75 & $0,298>0,05$ & Linier & 50,509 & 3,89 & Significant \\
\hline $\mathrm{X} 2 \rightarrow \mathrm{X} 3$ & 1,241 & 1,61 & $0,221>0,05$ & Linier & 44,409 & 3,89 & Significant \\
\hline
\end{tabular}


Table 3. Result of Pearson Correlations

Correlations

\begin{tabular}{|c|c|c|c|c|c|}
\hline & & $\mathrm{X} 1$ & $\mathrm{X} 2$ & $\mathrm{X} 3$ & Y \\
\hline \multirow{5}{*}{$\mathrm{X} 1$} & Pearson & 1 & $.411^{* * *}$ & $.465^{* *}$ & $.448^{* * 4}$ \\
\hline & Correlation & & & & \\
\hline & Sig. (2-tailed) & & .000 & .000 & .000 \\
\hline & $\mathrm{N}$ & 185 & 185 & 185 & 185 \\
\hline & Pearson & $.411^{* *}$ & 1 & $.440^{* *}$ & $.416^{* *}$ \\
\hline \multirow{4}{*}{$\mathrm{X} 2$} & Correlation & & & & \\
\hline & Sig. (2-tailed) & .000 & & .000 & .000 \\
\hline & $\mathrm{N}$ & 185 & 185 & 185 & 185 \\
\hline & Pearson & $.465^{* *}$ & $.440^{* *}$ & 1 & $.433^{* *}$ \\
\hline \multirow[t]{4}{*}{ X3 } & Correlation & & & & \\
\hline & Sig. (2-tailed) & $\begin{array}{l}.000 \\
185\end{array}$ & $\begin{array}{l}.000 \\
185\end{array}$ & 185 & $\begin{array}{l}.000 \\
185\end{array}$ \\
\hline & N & $\begin{array}{r}185 \\
448^{* *}\end{array}$ & $\begin{array}{r}185 \\
416^{* * *}\end{array}$ & $\begin{array}{r}185 \\
433^{* *}\end{array}$ & $\begin{array}{r}185 \\
1\end{array}$ \\
\hline & Correlation & & & & \\
\hline \multirow{2}{*}{ Y } & Sig. (2-tailed) & .000 & .000 & .000 & \\
\hline & $\mathrm{N}$ & 185 & 185 & 185 & 185 \\
\hline
\end{tabular}

**. Correlation is significant at the 0.01 level (2-tailed).

Based on the calculation of Pearson correlation obtained values of $\mathrm{r}_{\mathrm{y} 1}=0,448, \mathrm{r}_{\mathrm{y} 2}=0,416, \mathrm{r}_{\mathrm{y} 3}=0,433, \mathrm{r}_{13}=$ $0,465, \mathrm{r}_{23}=0,0,440, \mathrm{r}_{12}=0,411$.

Table 4. Coefficient Sub Structure 1

Coefficients $^{\mathrm{a}}$

\begin{tabular}{|c|c|c|c|c|c|c|}
\hline \multirow{2}{*}{\multicolumn{2}{|c|}{ Model }} & \multicolumn{2}{|c|}{$\begin{array}{c}\text { Unstandardized } \\
\text { Coefficients }\end{array}$} & $\begin{array}{l}\text { Standardized } \\
\text { Coefficients }\end{array}$ & \multirow[t]{2}{*}{$\mathrm{T}$} & \multirow[t]{2}{*}{ Sig. } \\
\hline & & $\mathrm{B}$ & Std. Error & Beta & & \\
\hline \multirow{3}{*}{1} & (Constant) & 37.440 & 5.287 & & 7.082 & .000 \\
\hline & $\mathrm{X} 1$ & .524 & .105 & .342 & 4.995 & .000 \\
\hline & $\mathrm{X} 2$ & .304 & .069 & .300 & 4.376 & .000 \\
\hline
\end{tabular}

a. Dependent Variable: X3

Based on the output of SPSS, for sub-structure 1, the effect of Competence on Performance is P13=0,342 and the influence of Social Capital to Performance is $\mathrm{P} 23=0,300$.

Table 5. Result of Sub Structure 1

\begin{tabular}{|c|c|c|c|c|c|}
\hline Path & $\begin{array}{l}\text { Path Coefficient } \\
\text { (P) }\end{array}$ & $\mathrm{T}_{\text {counted }}$ & $\mathrm{p}$-value & $\frac{t_{\text {table }}}{\alpha=0,05}$ & Result \\
\hline $\mathrm{X} 1 \rightarrow \mathrm{X} 3$ & 0,342 & 4,995 & 0,000 & 1,97 & Significant \\
\hline $\mathrm{X} 2 \rightarrow \mathrm{X} 3$ & 0,300 & 4,376 & 0,000 & 1,97 & Significant \\
\hline
\end{tabular}

The results of the above test are consistent with the findings of Samsul Bahri (2016) stating that the competence of employees has proved to have a positive and significant effect on employee performance. Employees who have good competence, usually have a good performance too, because it can easily understand the work. Furthermore Boulter, Dalziel and Hill in Sutrisno (2016), argued competence is a basic characteristic of a person who enables it to deliver superior performance in a particular job, role or situation. 
The test results are also in line with findings on the effect of Social Capital on Performance by Akmal Hudaykulov and Xu Hongyi (2015) that Social Capital affects both teamwork and therefore should be a factor considered by the organization. The human resources department can implement training activities aimed at increasing trust and recognition among team members to improve employee cooperation and performance. The wider the social network of a person, the higher the opportunity to exchange knowledge, technology, expertise, and other benefits and the higher the opportunity to be able to improve its performance.

Table 6. Coefficient Sub Structure 2

Coefficients $^{\mathrm{a}}$

\begin{tabular}{|c|c|c|c|c|c|c|}
\hline \multirow{2}{*}{\multicolumn{2}{|c|}{ Model }} & \multicolumn{2}{|c|}{$\begin{array}{c}\text { Unstandardized } \\
\text { Coefficients }\end{array}$} & \multirow{2}{*}{$\begin{array}{c}\text { Standardized } \\
\text { Coefficients } \\
\text { Beta }\end{array}$} & \multirow[t]{2}{*}{$\mathrm{T}$} & \multirow[t]{2}{*}{ Sig. } \\
\hline & & $\mathrm{B}$ & Std. Error & & & \\
\hline \multirow{4}{*}{1} & (Constant) & 18.704 & 5.422 & & 3.449 & .001 \\
\hline & $\mathrm{X} 1$ & .362 & .102 & .259 & 3.559 & .000 \\
\hline & $\mathrm{X} 2$ & .197 & .066 & .213 & 2.971 & .003 \\
\hline & X3 & .199 & .067 & .218 & 2.953 & .004 \\
\hline
\end{tabular}

a. Dependent Variable: Y

Based on the output of SPSS, for sub-structure 2 it is found that the effect of Competence on Career is PY1 $=0,259$ and the influence of Social Capital to Career is PY2 $=0,213$ and the influence of Performance to Career is PY3 $=0,218$.

Table 7. Results of Sub Structure 2

\begin{tabular}{|c|c|c|c|c|c|}
\hline \multirow{2}{*}{ Path } & Path Coefficient & \multirow{2}{*}{$\mathrm{T}_{\text {counted }}$} & $\mathrm{p}$-value & $\mathrm{t}_{\text {table }}$ & \multirow{2}{*}{ Result } \\
\cline { 4 - 5 } & $(\mathrm{P})$ & & $\alpha=0,05$ & \\
\hline $\mathrm{X} 1 \rightarrow \mathrm{Y}$ & 0,259 & 3,559 & 0,000 & 1,97 & Significant \\
\hline $\mathrm{X} 2 \rightarrow \mathrm{Y}$ & 0,213 & 2,971 & 0,003 & 1,97 & Significant \\
\hline $\mathrm{X} 3 \rightarrow \mathrm{Y}$ & 0,218 & 2,953 & 0,004 & 1,97 & Significant \\
\hline
\end{tabular}

Hutapea (2008) explains that Competence also affects the career related to knowledge, skills and work skills of a person for his field of work. Competence represents one's performance. From the competence of employees, the Human Resource management can know how a person is responsible, able to complete his job, able to solve problems and communicate in fostering good relationships related tasks instructed by superiors. In essence, competence can be used to plan, assist and develop one's behavior and performance. An employee should be aware of the attributes associated with a personnel career and a series of lifelong steps that contribute to career fulfillment.

The results of the above test results in line with the findings of Kartika Dewi and Riana (2015) show that performance appraisal and work experience have a positive effect on career development. According Sedarmayanti, performance appraisal results can be used as a basis for decision making to promote or demote employees.

Social Capital also affects the career in relation to the use of social capital to improve relationships between individuals and relationships between institutions by getting connection links through social networking it has. The findings of this study are also consistent with the results of Lucy Karimi Njagi (2012) study which revealed that Networking (social network) plays an important role especially in the workplace, the easier it is for them to maneuver in their way. improve performance by fostering good relations and establishing cooperation with various institutions for the purpose of organizational development.

So as a whole obtained the empirical causal model as follows: 


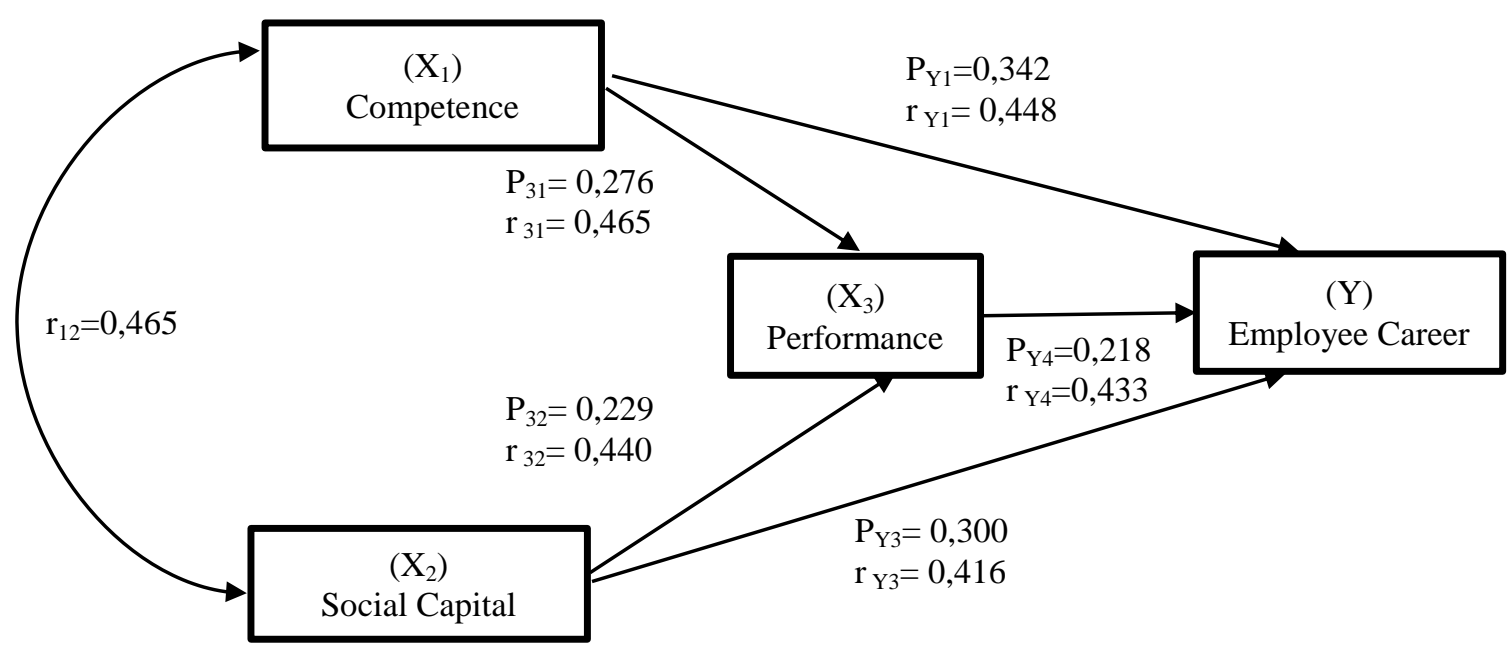

Figure 1. Causal Empirical Model

Table 8. Summary of Test Results of Statistical Hypotheses

\begin{tabular}{|l|l|l|l|l|}
\hline No. & \multicolumn{1}{|c|}{ Hypotheses } & $\begin{array}{l}\text { Statistic } \\
\text { Test }\end{array}$ & \multicolumn{1}{|c|}{ Result } & \multicolumn{1}{c|}{ Conclusion } \\
\hline 1 & $\begin{array}{l}\text { To analyze direct effect of } \\
\text { Administrative Competence } \\
\text { on Employee Career }\end{array}$ & $\begin{array}{l}\mathrm{H}_{0}: \mathrm{Y}_{\mathrm{Y} 1} \leq 0 \\
\mathrm{H}_{1}: \mathrm{Y}_{\mathrm{Y} 1}>0\end{array}$ & $\begin{array}{l}\mathrm{H}_{\mathrm{O}} \text { denied, } \\
\mathrm{H}_{1} \text { accepted. }\end{array}$ & $\begin{array}{l}\text { There is a } \\
\text { positive direct } \\
\text { effect. }\end{array}$ \\
\hline 2 & $\begin{array}{l}\text { To analyze direct effect of } \\
\text { Social Capital on Career } \\
\text { Employees }\end{array}$ & $\begin{array}{l}\mathrm{H}_{0}: \beta_{\mathrm{Y} 2} \leq 0 \\
\mathrm{H}_{1}: \beta_{\mathrm{Y} 2}>0\end{array}$ & $\begin{array}{l}\mathrm{H}_{\mathrm{O}} \text { denied, } \\
\mathrm{H}_{1} \text { accepted. }\end{array}$ & $\begin{array}{l}\text { There is a } \\
\text { positive direct } \\
\text { effect. }\end{array}$ \\
\hline 3 & $\begin{array}{l}\text { To analyze direct effect of } \\
\text { Performance on Career } \\
\text { Employees. }\end{array}$ & $\begin{array}{l}\mathrm{H}_{0}: \beta_{\mathrm{Y} 3} \leq 0 \\
\mathrm{H}_{1}: \beta_{\mathrm{Y} 3}>0\end{array}$ & $\begin{array}{l}\mathrm{H}_{\mathrm{O}} \text { denied, } \\
\mathrm{H}_{1} \text { accepted. }\end{array}$ & $\begin{array}{l}\text { There is a } \\
\text { positive direct } \\
\text { effect. }\end{array}$ \\
\hline 4 & $\begin{array}{l}\text { To analyze effect of } \\
\text { Administrative Competence } \\
\text { on Performance. }\end{array}$ & $\begin{array}{l}\mathrm{H}_{0}: \beta_{31} \leq 0 \\
\mathrm{H}_{1}: \beta_{31}>0\end{array}$ & $\begin{array}{l}\mathrm{H}_{\mathrm{O}} \text { denied, } \\
\mathrm{H}_{1} \text { accepted. }\end{array}$ & $\begin{array}{l}\text { There is a } \\
\text { positive direct } \\
\text { effect. }\end{array}$ \\
\hline 5 & $\begin{array}{l}\text { To analyze direct effect of } \\
\text { Social Capital on } \\
\text { Performance }\end{array}$ & $\begin{array}{l}\mathrm{H}_{0}: \beta_{32} \leq 0 \\
\mathrm{H}_{1}: \beta_{32}>0\end{array}$ & $\begin{array}{l}\mathrm{H}_{\mathrm{o}} \text { denied, } \\
\mathrm{H}_{1} \text { accepted. }\end{array}$ & $\begin{array}{l}\text { There is a } \\
\text { positive direct } \\
\text { effect. }\end{array}$ \\
\hline
\end{tabular}

\section{Conclusion}

1. Competence has a direct positive effect on the Employee Career. To improve his career, it can be done by increasing the knowledge of employees through training and rotation periodically and be flexible in dealing with the dynamics of work so that employees can carry out their work in accordance with organizational goals.

2. Performance has a direct positive effect on the Employee Career. Employees need to perform well because the performance appraisal results are used by HR management for employee promotion. Employees also need to learn from mistakes and overcome the fear of failing in his career so as to improve his performance and his career.

3. Social Capital has a direct positive effect on the Employee Career. Employees can take advantage of social capital starting from building a good self-image so trusted to build cooperation and given greater responsibility.

4. Competence has a direct positive effect on Performance. To improve its performance, it can be done by improving employees' knowledge through periodic training and rotation and being flexible in 
responding to work dynamics so that employees can perform their work according to organizational goals.

5. Social Capital has a direct positive effect on Performance. Employees can utilize their social capital to share knowledge and information related to their work thus contributing to improve their performance.

\section{References}

1. Aime, Federico, Linn Van Dyne, Oleg V. Petrenko, "Role Innovation Through Employee Sosial Networks: The Embedded Nature Of Roles And Their Effect On Job Satisfaction And Career Success", DOI: 10.1177/2041386611411230 opr.sagepub.com, 2012.

2. Akmal Hudaykulov, Xu Hongyi, The Effects of Sosial Capital On Team Performance: A Study of RD Departments in Uzbekistan, International Journal of Management Science and Business Administration, Volume 1, Issue 1, April 2015, Pages 80-91

3. Atthoillah, Model Peningkatan Knowledge Sharing Berbasis Modal Sosial Dan Learning Organization terhadap Kinerja Agency Pada Pt Prudential Life Assurance, EKOBIS Vol.18, No.2, July 2017: 174 - 183, 2017.

4. Caluwe, Chiara De, Wouter Van Dooren, Anita Delafortry, Ria Janvier, "Mind-Sets of Boundaryless Careers in the Public Sector: The Vanguard of a More Mobile Workforce?", Journal Public Personnel Management, Vol. 43(4) 490- 519 DOI:10.1177/0091026014528479 ppm.sagepub.com, 2014.

5. Chen Jian-Qiao, Zhi-Jin Hou, Xu Li, Kathi J. Lovelace, Yi-Ling Liu, Zhi-Li Wang, The Role of Career Growth in Chinese New Employee's Turnover Process, Journal of Career Development, 1-15 DOI: 10.1177/0894845315571412, jcd.sagepub.com, 2015.

6. Coetzee, M., Ferreira, N, \& Potgieter, I.L, Assessing Employability Capacities And Career Adaptability In A Sample Of Human Resource Professionals. SA Journal of Human Resource Management/SA Tydskrif vir Menslikehulpbronbestuur, 13(1), Art, \#682, 9 pages, http://dx.doi.org/10.4102/sajhrm.v13i1.682, 2015.

7. Creed, Peter A. Creed, Ruth-Eva Gagliardi, Career Compromise, Career Distress, and Perceptions of Employability: The Moderating Roles of Sosial Capital and Core Self Evaluations, Journal of Career Assessment, Vol. 23(1) 20-34, DOI: 10.1177/1069072714523082 jca.sagepub.com, 2015.

8. Dalal, Reeshad S., "Within-Person Variability in Job Performance: A Theoretical Review and Research Agenda", Journal of Management Vol. 40 No. 5, July 2014 1396-1436 DOI: 10.1177/0149206314532691 sagepub.com/journalsPermissions.nav, 2014.

9. Danang Sunyoto, Manajemen dan Pengembangan Sumber Daya Manusia, Yogyakarta: CAPS, 2015.

10. Dandy Rahman, Sri Wahyu Lely, Chairul Soleh, Pengaruh Kompetensi dan Kepemimpinan Terhadap Kinerja Karyawan Dengan Motivasi Sebagai Variabel Intervening (Studi Kasus Pada Karyawan Bagian Pabrik PT.Jember Indonesia), Artikel Ilmiah Mahasiswa 2014. repository.unej.ac.id/bitstream/handle/123456789/63998/Dandy\%20Rahman.pdf?sequence=1 accessed May 27, 2017

11. Dono Wirotomo, Popy Novita Pasaribu, "Pengaruh Kompetensi, Pengembangan Karir, Pendidikan Dan Pelatihan (Diklat) Terhadap Knerja Pegawai Direktorat Jenderal Perimbangan Keuangan",Jurnal MIX, Volume V, No. 3, Oktober 2015.

12. Edy Sutrisno, Manajemen Sumber Daya Manusia, Prenadamedia, p. 202-203, 2016.

13. Edy Sutrisno, Manajemen Sumber Daya Manusia, Prenadamedia, p. 158, 2012.

14. Erwin Thobias Drs. A.K. Tungka, Msi. Dra. J.J. Rogahang, Msi., Pengaruh Modal Sosial Terhadap Perilaku Kewirausahaan, Journal “ACTA DIURNA” Edisi April 2013.

15. Erwin Thobias, A.K. Tungka, J.J. Rogahang, Pengaruh Modal Sosial Terhadap Perilaku Kewirausahaan, Journal "ACTA DIURNA" Edisi April 2013.

16. Hutapea, Parulian dan Nurianna Thoha. Kompetensi Plus, Teori, Desain, Kasus dan Penerapan untuk HR dan Organisasi yang Dinamis, PT. Gramedia. Jakarta. p.27, 2008.

17. I.A.Putu Kartika Dewi, I Gede Riana, Pengaruh Penilaian Kinerja Dan Pengalaman Kerja Terhadap Pengembangan Karir Pada PT.Bali Biasa Indah Koleksi Kuta - Bali, E-Jurnal Manajemen Unud, Vol. 4, No. 7, 2015 : 1918-1933 ISSN: 2302-8912, 2015. 
18. John M.Ivancevich, Robert Konopaske, Human Resource Management, Mc Graw-Hill International Edition, p. 4, 2013.

19. Koh, Kyungwon, June Abbas, Competencies for Information Professionals in Learning Labs and Makerspaces, Journal of Education for Library and Information Science, Vol. 56, No. 2-(Spring) April 2015 ISSN: 0748-5786, DOI:10.12783/issn.2328-2967/56/2/3, 2015

20. Lucy Karimi Njagi, Relationship Between Sosial Capital And Employee Promotion, International Journal of Business and Commerce Vol. 1, No.10: Jun 2012 [01-13] (ISSN: 2225-2436), www.ijbcnet.com

21. Moeheriono, Pengukuran Kinerja Berbasis Kompetensi, Jakarta: Raja Grafindo, p.315, 2012

22. Nuryanto, Murakhman Sayuti Enggok, Akhmad Abdurrahman, "Pengaruh Kompetensi Terhadap Produktivitas Kerja Pegawai Kantor Unit Penyelenggara Pelabuhan Kelas III Satui”, Administraus - Jurnal Ilmu Administrasi dan Manajemen Vol 1, No 1 - September 2017.

23. Raymond A.Noe, John R. Hollenbeck, Barry Gerhart, Patick M.Wright, Manajemen Sumber Daya Manusia, McGraw-Hill, h.570, 2010.

24. Renowati, "Jaringan Sosial Gereja Kristen Jawi Wetan (GKJW) Dengan Pondok Pesantren Di Malang Jawa Timur", Jurnal Analisa Pengkajian Masalah Sosial Keagamaan, Volume 20 Nomor 01 Juni 2013, p. 39.

25. Samsul Bahri, Pengaruh Pengembangan Karier Dan Kompetensi Terhadap Produktivitas Kerja Serta Implikasinya Pada Kinerja Pegawai Dinas Pu Bina Marga Wilayah Kerja Sumatera Selatan, Jurnal EComent Global, Volume 1 Nomor 1 Edisi Februari 2016, ISSN: 2540-816X, p. 51-61

26. Saud Napitupulu, Tulus Haryono, Asri Laksmi Riani, Hunik Sri Runing Sawitri \& Mugi Harsono: The Impact Of Career Development On Employee Performance: An Empirical Study Of The Public Sector In Indonesia, International Review of Public Administration, DOI: 10.1080/12294659.2017.1368003, 2017.

27. Sedarmayanti, Manajemen Sumber Daya Manusia: Reformasi Birokrasi dan Manajemen Karyawan Negeri Sipil Bandung, PT. Refika Aditama, p.264-265, 2014.

28. Stephen R. Covey, The 7 Habits of Highly Effective People, Covey Leadership Center, Jakarta: Binarupa Aksara, 1997, h. 23, 1997.

29. Suh, Yo Jin, The Role of Relational Sosial Capital and Communication in the Relationship Between CSR and Employee Attitudes: A Multilevel Analysis, Journal of Leadership \& Organizational Studies, Vol. 23(4) 410423 DOI: 10.1177/1548051816637564 jlo.sagepub.com, 2016.

30. Umar Makawi, Normajatun, Abdul Haliq, Analisis Pengaruh Kompetensi Terhadap Kinerja Pegawai Dinas Perindustrian Dan Perdagangan Kota Banjarmasin, Jurnal Al - Ulum Ilmu Sosial Dan Humaniora Issn: 2476 - 9576 Volume 1 Nomor 1, Oktober 2015, p.16-26.

31. Veithzal Rivai, Manajemen Sumber Daya Manusia Untuk Organisasi: Dari Teori Ke Praktik, Raja Grafindo Persada, Jakarta, p.548-549, 2013.

32. Weer, Christy H., Jeffrey H. Greenhaus, Managers' Assessments of Employees' Organizational Career Growth Opportunities: The Role of Extra-Role Performance, Work Engagement, and Perceived Organizational Commitment", Journal of Career Development, p.1-16, DOI: 10.1177/0894845317714892 journals.sagepub.com/home/jcd, 2017.

33. Wibowo, Manajemen Kinerja, Jakarta: Raja Grafindo Press, p.7, 2014. 